\title{
International Business Travel in a Digital World Economy
}

Jonathan V. Beaverstock and Lucy Budd, Volume Editors

International business travel involves the trans-border movement of hundreds of millions of people each year and is a phenomenon that both drives and is driven by processes of continued globalisation and the intensification of an international world economy (see Beaverstock et al, 2009; 2010; Davidson and Cope, 2003; Faulconbridge et al, 2009; Welch and Worm, 2005). Defined by Aguilera (2008 pp1109-1110) as 'work-related travel to an irregular place of work (for example: to visit a client, participate in a conference or attend a meeting)', business travel has become one of the defining features of working life for millions of people around the globe and a normal part of their professional routines. As Welch, Welch and Worm (2007, pp174), specialists in the field of international human resource management, have observed:

“... international business travellers (IBTs) are persons for who a part generally a major part - of their role involves international visits to foreign markets, units, projects and the like ... business travel is an essential component of their work ... For some, ... [IBT] ... has evolved to the point of being almost a career in itself".

The contribution international business travel makes to the world economy is highly significant. A recent survey published by the World Travel \& Tourism Council (WT\&TC) (2011), which was commissioned to Oxford Economics, noted three key findings:

- Business travel has improved global productivity, yielding a rate of investment of $10: 1$;

- International business travel has generated approximately one third of the growth in global trade over the last decade;

- Over 40 million jobs were created by the multiplier effects of international business travel through more trade and higher productivity between 2000 and 2007. 
Moreover, beyond the role that international (and domestic) business travel plays in generating economic multiplier effects at the global scale (see WT\&TC, 2011), it also has a major economic input into other sectors, including commercial aviation, car rental businesses, train operating companies, accommodation providers, event management firms and electronic payment systems (including credit cards, corporate travel schemes and internet transactions) through the direct spending of business travellers both at home and overseas.

Many national governments produce official data on the scale and scope of business and leisure travel that is undertaken both domestically and internationally, including recording the number of travellers and travel visits, points of origin and destination, travellers' nationality, modes of transport, and importantly, travellers' purchasing power and spending habits. All of these data can contribute to the production of local, regional and national transportation and infrastructure planning, and models which forecast economic growth. For example, data about international business into and out of the UK is collected by the Government's Office for National Statistics (ONS). Each year, the ONS collects data on international business travel in its Travel Trends series which is based on data obtained from asking arriving and departing passengers (both UK residents and foreign nationals) about their motivation for entering or leaving the country for periods of less than one year.

Between 1992 and 2007, there was an average year on year growth rate of about $+5 \%$ for both overseas residents entering the UK and UK residents leaving the country for business purposes (ONS, 2008). In 2008, 8.124 million business visits were made to the UK by overseas residents and 8.920 million overseas trips were made by UK residents. The majority of all these journeys were completed by air (74\% and $83 \%$ respectively) (ONS, 2013). In 2008, overseas business travellers brought an estimated $£ 4,575$ million GBP pounds into the UK economy. During the worst of the global economic crisis (2008-2012) however, the 5\% annual average growth rate for international business travel slowed. By 2012, the number of overseas residents visiting the UK for business purposes had declined to 7.422 million and their estimated annual spend was $£ 4,501$ million (ONS, 2013). Conversely, UK residents made 6.956 million business visits outside of the UK in 2012 (down 6\% on 2008 figures) and spent approximately $£ 4,841$ million in their countries of destination (ONS, 2013). Beyond these numbers, estimating the multiplier effects of business travel to, from and within the UK economy is often the domain of the corporate business 
industry (for example, Carlson Wagonlite Travel) and firms which feed into this sector of the economy (for example, the major credit card companies like Barclaycard and AMEX).

Although international business travel is far from a new phenomenon and historical records show that people have been travelling aboard to sell products, exchange ideas and develop new markets for tens of thousands of years, the development of new forms of transportation technology and new modes of business organisation in the late twentieth and early twenty-first centuries have both enabled but also demanded new forms of mobile lives and obliged ever growing numbers of people to work 'on the move' (see for example, Geografiska Annaler B, 2009).

Tellingly, confident predictions a decade or more ago that a new generation of ICT and high-speed internet would render business travel obsolete appear premature indeed as the 'compulsion' to move, even in an era of Skype, Facetime, instant messaging and video conferencing, remains very strong. Indeed, it has been persuasively argued that improved ICT provision and high-speed broadband internet connections have actually stimulated further demand for physical travel as they have enabled people to make connections that otherwise would not have occurred. In July 2013, for example, one of Europe's biggest low cost airlines, easyJet, ran a full-page advertisement in British broadsheet newspapers which reminded would-be passengers that ' $A$ handshake is worth a thousand emails... Trust is more important than ever and it's hard to build from 600 miles away'.

All this is, of course, good news for transport providers whose business models have long been dependent on the revenues obtained from business travellers. In terms of mode share, by far the majority of international business travel occurs by air. In 2012, the world's airlines collectively carried over 2.8 billion passengers (ATAG, 2012), a substantial proportion of whom were travelling for business purposes. The utility of aircraft and air travel for business purposes was recognised almost from the inception of powered flight at the beginning of the twentieth century and pioneering commercial airlines were established to meet the mobility needs of wealthy business travellers and urgent shipments of perishable cargo and mail. As the twentieth century progressed, new aircraft technology combined with changing regulatory regimes lowered the financial cost of air tickets and enabled more people to fly more cheaply for both business and leisure purposes. Consequently, the commercial imperative to capture and retain the custom of 
lucrative business travellers (irrespective of their class of travel) has become ever more acute and has been responsible for driving continual product and service innovations as airlines compete with one another to offer the most attractive in-flight product and superlative levels of personal comfort and service. Long-distance international train and coach operating companies have also incorporated elements of the aircraft cabin, in the form of improved seat comfort, better catering, on board wi-fi and personal power sockets, into railway carriages, coaches and buses in an attempt to enhance the potential productivity of travellers' journeys.

Trains, and particularly trans-continental providers like Eurostar, TVG, Thalys and ICE have also benefited from the business traveller market in both their business and leisure (standard) carriages. Eurostar, which links Paris and Brussels with London St. Pancras International (which also increasingly acts as a rail gateway to other countries in continental Europe), has been relatively successful in capturing market share in the lucrative UK-French/Belgium aero-business travel corridor. Data from the ONS $(2013,2004)$ suggests that business travel to and from the UK by both overseas and UK residents using Eurostar through the Channel Tunnel has remained relatively stable during the global financial crises and recession in the Eurozone. In 2002 and 2012, the total number of business visits to and from the UK using the Tunnel accounted for $12 \%$ (1.78 and 1.674million respectively) of the total number of business visits, with a dip between 2008 and 2011 (-17\%), and strong recovery between 2011-2012 (+12.5\%) (ONS, 2012, 2004). Comparable passenger data from Eurostar corroborate the general ONS Travel Trends for using the Tunnel. In 2012, the operating profits of Eurostar more than doubled from the previous year (from $£ 25 \mathrm{~m}$ to $£ 52.2 \mathrm{~m}$ ) with business travellers remaining stable, but of course, the company was significantly boosted by the London Olympics, which we would argue would have generated an uplift in travel for business purposes in all tariffs of carriage (see, http://railjournal.com/index.php/financial/eurostar-reports-increased-profit-andpassengers-in-2012.html, accessed 04/09/2013). During 2013, Eurostar reported an uplift of about $+3 \%$ in business travel compared to 2012 and was optimistic about the growth in this segment of passenger numbers in the coming year (http://www.eurostar.com/uk-en/about-eurostar/press-office/pressreleases/2013/eurostar-growth-gathers-pace, accessed 04/09/2013). As Europe slowly moves out of recession, the Tunnel business traveller corridor between London-Calais-Lille-Paris and Brussels (with connections to the South of France, 
Alps and Germany/Netherlands) will continue to present a competitive challenge to the usual airline routes from the UK to continental Europe.

The recent global economic recession and the period of austerity it subsequently created resulted in sudden and dramatic shifts in the international business travel environment. While the very high-end bespoke business travel operators, such as 'VVIP' private jet charters and other providers of elite mobility, have appeared largely immune from the recession's effects (see Budd, 2013), sections of the more 'mainstream' business travel market were more severely affected. Business-class only airlines, including US-based Eos and Maxjet and UKregistered Silverjet, all of whom operated transatlantic services between the USA and UK, were forced to leave the market. Indeed, as corporate restructuring, redundancies and bankruptcies took told and travel budgets and discretionary spending declined worldwide, some transport providers, including many of the world's major full-service airlines, repositioned themselves to appeal to more price sensitive consumers by launching 'lower frills' lower-priced products.

Low cost airlines, in particular, sought to present themselves as logical and natural alternatives to the perceived expense and apparent profligacy of full-service operators who had previously tempted business travellers to their services with the lure of fluffy pillows, cashmere blankets, frequent flyer rewards and designer ijn-flight amenity kits. EasyJet, for example, introduced a series of new brand propositions that explicitly targeted business travellers. Their 'You're in business, work it out', 'The new shape of business travel' and 'That's business sense' marketing campaigns both individually and collectively sought to present the carrier as a rational choice for business travellers and remove some of the 'snobbishness' that might previously have prevented business travellers from flying with low cost operators (see Mason, 2000 , for a detailed discussion of business travellers' propensity to use low cost airlines).

The apparent polarisation of business travel between the top and bottom of the market created an interesting dichotomy between those providers who emphasised the frequency, convenience, utility, and cost effectiveness of their services and those who claimed that a comfortable, rested and less stressed worker would ultimately be more productive. By way of illustration, Continental Airlines of the United States ran an advertisement in 2005 which proclaimed that in their awardwinning 'Business First' cabin 'Martinis arrive shaken or stirred. You don't' and the 
superior comfort and pitch of aircraft seats, high standards of inflight cuisine and levels of personal service customers are common rhetorical devices that are routinely employed by many of the world's leading passenger airlines.

Yet, almost irrespective of whether a business traveller is travelling to sales meetings, a conference, an interview or a strategy meeting overseas, luxuriating in the relative comfort of First Class or travelling in economy, the subliminal message has long been clear- business travel is both a facilitator and an indicator of personal and professional success and achievement and, in some cases, has even been portrayed as a deliberate lifestyle choice (as George Clooney's character Ryan Bingham in the 2009 movie 'Up in the Air' which was based on Walter Kirn's novel of the same title suggested). While we recognise that there is no such thing as a 'typical' business traveller and we appreciate that there are widespread variations in rates of business travel both within and between world regions, individual countries and socio-demographic groups, we nevertheless contend that international business travel, irrespective of whether it is undertaken weekly, monthly or annually has become part and parcel of everyday life for many. 'Survival guides' to international business travel detail the 'tricks of the trade' for the uninitiated and provide strategies on how to cope with jet lag, packing and making airport transit times more productive (see Crainer and Dearlove, 2001).

Although the rhetoric of routine transnational mobility in which the world is moving faster and more frequently than ever before, which has long dominated discourses of business travel, is increasingly being challenged by those who assert that travel, whether by land, sea, or air, imposes a range of serious social, cultural and environmental challenges, business travel is likely to remain an omnipresent feature of the world economy for many years to come. The present scale, scope and future development potential of international business travel thus poses a number of challenging business and management implications, not least for transport service providers, corporations who purchase business travel, individual business travellers who undertake routine or occasional (often long-distance) journeys for work, and the countries involved in outbound and inbound flows of travellers.

The contemporary scale and scope of international business travel has rendered it a multi-million dollar annual enterprise that involves thousands of companies at all stages of the service delivery change, from reservations, loyalty programmes, and hotel providers, to insurance firms, transportation service providers and corporate 
travel agents. Often, these companies are linked to other providers on the ground local transportation (car rental) and the international hotel industry. Business travel occurs on all six permanently inhabited continents and its economic contribution is such that a growing number of companies, websites and specialist consumer magazines have been established to document the latest innovations and developments in business travel and provide bespoke corporate travel services and mobility solutions to firms and individual business travellers alike. It has been described as both a barometer of, and a supporter of, the health of the global economy. Yet for all its myriad social, spatial, organisational and economic implications, relatively little has been written about the agency of international business travel, beyond a range of vignettes detailing the organizational requirement for physical proximity.

We contend that international business travel warrants much more detailed empirical investigation to better understand its agency in the world of work and its impacts on global and regional economic development, travel providers, corporate customers, individual travellers and the environment. This is not to say that academia is devoid of studies of business travel. Indeed, the motilities turn has enabled an expansive body of research to be conducted into corporeal and virtual mobilities, transnational corporations, face-to-face and business-to-business transactions and other issues that direct relate to business travel. This work provides valuable insights into the role of business travel in addressing the apparent 'compulsion of meetingness' and the need for face-to-face contact in developing trust and professional relationships (Urry, 2003). However, absent from many of these debates is a consideration of the business and management implications international business travel poses for providers, facilitators and end users. Purpose of the special issue

The seven papers presented in this special issue focus on some of the complex implications international business travel poses for practices and policies of transportation business and management worldwide. Purposefully multidisciplinary in scope, it brings together some of the leading names in business travel research and innovation to offer new theoretical and empirical insights into contemporary practices, processes and policies of business travel in an increasingly interconnected, environmentally conscious and resource depleted world where businesses and individuals are being expected to do more with less. 
The first paper by Zachery Neal focuses on the evolution of the business air travel network in the US in the period from 1993 to 2011 and presents an empirical contribution to our understandings of international business travel discourse and management practice. Original data from the AIRNET programme examines business passengers' mobilities among 108 US metropolitan areas on an annual basis between the time-frame, and identifies the substantive travel nodes (cities) and volumes of flows (routes) between cities at the dyad level. At the node (city) level, the data indicated that New York, Los Angeles, San Francisco, Washington DC and Chicago dominated the annual share of business passengers travelling within the USA. In contrast, at the dyad or route level, the analysis identified major pairs of business travel routes, like for example New York to Los Angeles and Boston to Dallas. As for management practice, the paper makes a number of observations about emerging high volume business passenger routes, thus identifying possible new markets for transport providers and associated assemblages of corporate travel.

The second contribution by Tom Storme, Jonathan Beaverstock, Ben Derudder, James Faulconbridge and Frank Witlox examines the compulsion and copying strategies of academic business travel and mobility of tenured faculty at the University of Ghent, Belgium. Their quantitative research analysed over 8,000 faculty (lecturers and professors) travel applications and supplemented them with 23 semi-structured interviews with academic travellers. This in-depth study of academic business travel behaviour in a complex organisation found that that the majority of faculty had low travel behaviour, but those who did travel travelled frequently in order to participate in conferences, to undertake research and take part in exchanges. Importantly, the research highlighted the coping strategies adopted by both men and women travellers to cope with the work-life balance of the obligation to travel and the obligation to be at home.

In large businesses such as Universities, business travel itineraries and reservations are often handled by external corporate travel firms. In the third paper in this issue, Per Gustafson (2013) investigates the organisational practice of corporate travel management, drawing on interviews with travel managers and textual analysis of travel documents and associated policies. This qualitative approach unpacks the intermediary role of the travel manager (who manages the traveller for the organisation) and sheds further light on travel policy for business travellers, planning, bookings and post-travel. The most significant implication of this work for the 
transportation management practice is illustrating with evidence-based research the process of travel management and intermediary role of the manager at different moments in the business travel cycle.

The business traveller's organisational role and personal network strategies is the subject of Tom Julsrud and Anne Gjerdåker's essay in the context of long distant travel and 'face-to-face' working practices within global firms. Drawn from an interview survey of 18 managers across ten different industries based in Nordic countries, the research identified four personal networking strategies for business travel: sustaining networks (preserving and strengthening existing networks); exploiting networks (generating new knowledge and information with exiting contacts); entrepreneurial networks (developing new connections); and representing networks (where pre-existing ties are weak or newly developed). Importantly, the research findings will hearten the transportation management practice because the organisational compulsion for face-to-face contact and meetings will continue to sustain international business travel irrespective of innovation in ICT systems.

The fifth paper, by Lucy Budd and Tim Vorley, examines one recent development in ICT innovation that supports business travel. The growing use of internet-enabled smartphones and tablet computers have allowed travel firms to produce a range of mobile software applications (apps) that purport to support business travellers by enabling them to make and amend travel reservations on the move, receive real time journey updates and access a range of information about their intended destination while away from the office. Through an in-depth analysis of the official apps that are produced by the World's 25 largest passenger airlines, the paper proposes that the development of mobile technology is precipitating a shift away from eCommerce towards an enhanced system of anytime and anywhere mobile customer relationship management in which the emphasis is on individual customisation, flexibility and efficiency. However, while mobile apps undoubtedly represent a technological innovation, that paper questions the extent to which they effect innovations in passenger service and reflects on the challenges and utility of mobile apps for future practices of international business travel.

Following on from this, the paper by Glenn Lyons focuses on one of the major compulsions for initiating and performing business travel - the requirement to attend business meetings in a face to face capacity. After a close examination of what actually makes up business travel and the complex nature and motivations 
underpinning co-presence, the main thrust of the paper examines the rationale and opportunity costs of business meetings with respect to time and travel and the (possible) reshaping of business meetings by ICT. Lyon's presents a compelling argument to reduce briefcase travel and notes that the challenge of lessening the volume of business travel that is undertaken (both for environmental and personal reasons) is the responsibility of both an organisation and individual employees to curtail unnecessary meetings and evaluate when and how meetings should be conducted, if at all.

In the final paper in this issue, Andrew Jones argues that there is a lack of precision in the definition and theoretical understanding of business travel and mobility which is unhelpful both for transportation management practice and industry as it faces the new challenges of moving people across-borders in an era of austerity and rapidly changing ICT systems. In essence, Jones focuses on the formulation of a new conceptual typology of different international business travel practices which seeks to explain and understand its role in the economic performance of both organisations and region. Importantly, Jones makes a number of very valuable observations for transportation management and practice, with perhaps the most significant arguments focused on the relationships between business travel mobility and new forms of ICT and mobile working.

Collectively the contributions highlight not only the diversity of patterns, processes and practices of international business travel but also the variety of methodological and empirical approaches that can be applied to better theorise, conceptualise and visualise it. However, despite the evident diversity and complexity of international business travel, a number of common narratives and themes emerge not least among which is the need for on-going transdisciplinary research into facets of business travel that have either been hitherto overlooked or which are emerging in response to new innovations in ICT, changing regulatory and/or political environments and growing concerns among certain sections of global soecity to aspire to a better work-life balance and limit or mitigate the environmental consequences of business travel in a world of economic uncertainty, population growth and increasing scarce natural resources. 


\section{References}

Aguilera, A. (2008): 'Business travel and mobile workers', Transportation Research Part A: Policy and Practice 42 (8): 1109-1116.

ATAG (2012) Aviation: Benefits beyond borders. Air Transport Action Group. Retrieved from www.benefitsbeyondborders.com on 20/06/2013.

Beaverstock, J.V., Derudder, B., Faulconbridge, J. R. and Witlox, F. (2010) (Eds.) International business travel in the global economy Farnham, Ashgate.

Beaverstock, J.V., Derudder, B., Faulconbridge, J. R. and Witlox, F. (2009): 'International business travel: some explorations', Geograpfiska Annaler: Series B, Human Geography 91 (3): 193-202.

Budd, L. (2013) Aeromobile elites: the role of private business aviation in the global economy in Burchell T and Caletrio Garcera, J. (Eds.) Elite Mobilities pp78-98 Farnham, Ashgate.

Crainer, S. and Dearlove, D. (2001) The Financial Times Guide to Business Travel the smart companion for hassle-free and productive trips Harlow, Pearson.

Geograpfiska Annaler: Series B, Human Geography (2009) Themed Issue on International Business Travel, volume 91 (3)

Davidson, R. and Cope, B. (2007): Business Travel. Pearson, Harlow.

Faulconbridge, J. R., Beaverstock, J. V., Derudder, B. and Witlox, F. (2009): 'Corporate ecologies of business travel in professional service firms: Working towards a research agenda', European Urban and Regional Studies 16 (3): 295-308.

Mason, K. (2000) The propensity of business travellers to use low cost airlines Journal of Transport Geography 8(2) pp107-119.

Office for National Statistics (2013) Travel Trends (available from www.ons.gov.uk) 
Office for National Statistics (2008) Travel Trends (available from www.ons.gov.uk)

Office for National Statistics (2004) Travel Trends (available from www.ons.gov.uk)

Urry, J. (2003): 'Social networks, travel and talk', British Journal of Sociology 54 (2): $155-175$.

Welch, D. E., Welch, L. S. and Worm, V. (2007): 'The international business traveller: a neglected but strategic human resource', International Journal of Human Resource Management 18 (2): 173-183.

Welch, D. E and Worm, V. (2005): 'International business travellers: a challenge for IHRM', in Stahl, G. K. and Bjorkman, I. (Eds) Handbook of Research in International Human Resource Management. Edward Elgar, Cheltenham, 283-301.

World Travel \& Tourism Council (2011) Business travel: A catalyst for economic performance (available from: http://www.wttc.org/research/specialresearch/business-travel-research/) 